\title{
BOLIN: Linguistic and Literary Journal
}

\author{
Josimar Gonçalves Ribeiro, Maria Catarina Paiva Repolês \\ Instituto Federal do Sudeste de Minas Gerais, Campus Rio Pomba, Brazil
}

\begin{abstract}
This article proposes a pedagogical strategy to develop proficiency in writing and comprehension in native and foreign languages. It is a pilot project which intends to explore, develop, build, collect, select, analyze, and prepare an action plan for that purpose. The strategy is being used at a Federal Institute in Brazil-IF Sudeste MG, Rio Pomba campus. The subjects involved in this process of investigation are students of two classes who attend their first year at High School integrated to technical courses. The methodology involves the use of a school journal as a teaching and learning resource to encourage literary reading and the production of different genres. The goal is to establish an interaction between the reading and writing mediated by a young and playful context offering an additional instrument for instruction, aimed at the use and reflection of the language.
\end{abstract}

Keywords: school journal, teaching resource, genre production

\section{Introduction}

The Federal Institute of Education, Science and Technology—Rio Pomba campus in the State of Minas Gerais, Brazil offers technical courses in both modalities, present and at distance which are: High School integrated to technical areas (Agriculture, Food, Forestry, Computing, and Animal Science); Concomitant and Subsequent courses, Undergraduate and Postgraduate Lato Sensu and Stricto Sensu. The main identity of these courses is the rural axis, even though some courses related to the urban world are being introduced. The students come from different places, both the field and the city, and from different economic classes.

Most students who enter their first year at high school, at the Federal Institute in Rio Pomba, have attended schools devoid of resources as lack of appropriate learning material, inaccessibility to educational innovation and to cultural diversity since they live in places which present difficulties to mobility and transportation. This has caused almost a reading invalidity of any discursive genres by these students, bringing poor reading comprehension and deficiency regarding the correct orthography.

Considering these facts, this paper exposed initially as a pilot project, seeks to improve reading and writing skills mediated by different genres. The goal is to add suggestions and adaptations to the teaching/learning of native and foreign languages to improve the ability of reading and writing knowledge.

The aim is then, to offer a journal as a teaching/learning resource which features a young and playful format so as to encourage the love of reading through indications of major literary works. And with that, motivate

Josimar Gonçalves Ribeiro, Instituto Federal do Sudeste de Minas Gerais, Campus Rio Pomba, Mestranda em Educação at Universidade Católica de Petrópolis - RJ.

Maria Catarina Paiva Repolês, Instituto Federal do Sudeste de Minas Gerais, Campus Rio Pomba, Doutoranda em Estudos de Linguagens at Centro Federal de Educação Tecnológica de Minas Gerais - MG. 
adolescents through various types of discursive texts from various fields to boost creativity at the time of textual composition. This journal called BOLIN — Linguistic and Literary Journal has the function to access and realize texts presenting the language as an expression of power in cultural production linking theory to practice.

What has justified the search for this pedagogical strategy that tried to be more effective in driving knowledge will be outlined in the next paragraph.

A student failure is related to the difficulty of textual interpretation, which is sustained by a culture rooted in a dislike of reading. Reading is not seen by Brazilians as a leisure option. According to TELES (2015), a research by Fecomercio RJ, pointed up that no books were read by $70 \%$ of Brazilians in 2014. The data reveals the exclusion of certain types of culture by the population and reveals the failure of the role played by the school, since it cannot instill in its students the pleasure of reading a book.

This aspect conflicts with school purposes, since it would be responsible for education and training of the individual. And since efficient reading and writing skills are necessary in the construction of the professional profile, many graduates come unprepared to the work market, accentuating the indifference to the ideological issues of society.

These circumstances attest to the lack of knowledge in reading which causes difficulty in textual interpretation and problems in writing. This is because there is lack of interest in culture-loaded words contained in any support for texts display. Thus, where there is little reading, it appears embarrassment with understanding records followed by discomfort at the time to articulate ideas in favor of some thoughts that deserve writing.

The thought of this inconvenience has boosted the search for a pedagogical strategy that would excel in teaching and learning by using resources that could spread the language in a fun, dynamic, and usual ways. So, in the next segment it will be stated the goals of this project.

The primary objective is to propose a pedagogical strategy to develop writing and interpretive competence. The pilot project shows evidence of being the journal BOLIN a teaching tool to encourage reading and production of various genres.

In this context, we seek to increase written skills and mental and intellectual capacity of students of the Integrated High School, Campus Rio Pomba, supported by the concept of literacy by Soares (2005a, p. 50), which underlies "the set of knowledge, attitudes and skills involved in the use of language in social practices, and necessary for an active and responsible participation in the written culture".

After exposing the problem and seeking a relationship among literacy, journal, textual genres, and writing of students, the question that guides the development of our objective is to what extent the development and dissemination of a journal can develop students' writing skills and interpretation. From this questioning, we will pursue the theoretical frame that will accompany the pilot project.

\section{Theoretical Frame}

\section{Textual Genres}

The world around us presents infinite models of texts that are called by Marcuschi (2003) as textual genres. These formats are endowed with specific characteristics that regulate the different types of texts. According to him, they are historical phenomena, deeply linked to cultural and social life and are responsible for concrete presentation of communication. 
Therefore, for this author, to consider a genre it is necessary to follow certain principles:

(1) Structural Form (graphic; footnote; discussion; poem)

(2) Communicative purpose (erratum; address)

(3) Content (shopping receipt; novel summary)

(4) Transmission medium (phone, telegram, e-mail)

(5) Roles of partners (oral examination; authorization)

(6) Situational context (conversation; personal letter). (Marcuschi, 2008, p. 164)

Genres are associated with social, historical constitution, and it may be difficult to establish recognition since they connect themselves to others, they merge themselves to build others. However, when identification is imposed, their function is to be emphasized, that is, the communicative purpose must be considered.

The text types are organizational structures where genres subordinate to a specific nature materializing in many ways interrelated to a communicative function. This relationship is directed to a "sphere of human activity" Marcuschi (2008, p. 155), or, the placement context, its social inclusion to the linguistic system in operation and the writing borders.

In the communication context, man's purpose is to transmit information, culture, ideology, and other manifestations of knowledge. So, for the realization of our social practices a person creates various textual forms to produce the propitious communicative situation. These creations, identified as genres, aim at encouraging communication between people and at expanding academic and world knowledge, therefore:

$[\ldots]$ they should be seen in relations with social practices, cognitive aspects, interests, power relations, technologies, discursive activities, and in the culture. They change, merge, blend themselves to keep their functional identity with organizational innovation. (Marcuschi, 2006, p. 25)

It is known that to live in community human beings need to identify various forms of texts and produce them in an active and responsive manner. The suggestion presented in this project is to provide the study of different genres with the objective to facilitate their recognition and afterwards their production, as it is believed by Marcuschi (1996, p. 15): "That who understands a text always produces, even mentally, another text at the same time".

Following it will be known, more deeply, about the journal and how it functions. Besides that, it will be commented its positive and negative aspects.

\section{The Journal}

The textual support ${ }^{1}$ journal has the main function to provide information to a specific public. It becomes an instrument of communication and a teaching/learning tool when inserted in the school context. And this is due to its immeasurable power to influence individuals who are involved in the process.

The reason for choosing this support enshrines up by offering different forms of representation of language that are established by a situation in the discourse model. In addition to this factor, we emphasize, according to the National Curricula Parameters (PCN), the "recognition of valuing the written language as a means of information and transmission of culture" (Brasil, 1998a, p. 8).

\footnotetext{
1 According to the New Aulete, contemporary Portuguese dictionary (2011, p. 1298): "Support [...] 4. Any materials (paper, tape, film, CD, etc.) in which one can record various types of information, such as text, pictures and sounds etc. [...]".
} 
An important point to add about this support is that it is able to interfere with the discourse. It has the communicative specificity to post texts and make them accessible. That is the opportunity for students to deal with the variety of textual genres a journal can embrace.

The relationship between support and genre is eccentric, as it has not yet been established by the researchers such is the level of coordination and involvement that one exercises on the other.

The definition to support, according to Marcuschi (2008, p. 174), is: "[...] A physical or virtual locus with specific format which is the basis or setting environment for the genre materialized as text" and it consists of three structures: "support is a place (physical or virtual); it has a specific format; it serves to set and display the text" (ibidem, p. 175).

The use of a journal as a teaching/learning resource is worth for offering another device for instruction, aimed at the use and reflection of the language. This object enables you to develop "[...] use of skills (textualization and reading comprehension) and metalinguistic reflection on the use" (Bonini, 2011, p. 152).

However, the pilot project in question differs in pedagogical aspects from other types of school papers for leading the whole performance towards literature. The dynamics signals to the intense encouragement of different types of reading that can culminate in the creation of different genres and thus enable the autonomous construction of the student as author.

Thus, the first BOLIN proposed an association between the goals to inform and offer a literary environment. In this way, some genres which are, in general, part of a regular paper, were worked in the editorial, poll, interview, synopsis of books, biography, students' opinions, comic strip, all related to the literary focus which was worked in class. The texts worked were exhibited in the light of the discursive field that is defined according to Marcuschi (2008, p. 194) as "[...] a sphere of social and institutional life in which occurs practices that organize forms of communication and their respective strategies of comprehension".

So this environment appointed by BOLIN seeks to distance itself from the negative influence that the media extends to people, in general, and is dedicated to a model:

[...] balanced, on one hand, considering the participation of teacher(s) and students on its authorship and, secondly, in terms of how it will reflect the conventional newspaper (necessary, so that there is the practice of media and journalistic literacy) and how much it will respect those specific subjects (who are not journalists, but students), possibly favoring their expression as authors and therefore as social protagonists (something that is necessary) so that the paper exists as an expression of media and students interaction. (Bonini, 2011, p. 162)

The study will now continue with rooting towards the crux of the matter, which is the functional use of language.

\section{Literacy}

With the new studies, the art of teaching has received other extensions of meaning. There was a need to distinguish the terms literacy (alfabetização: the ability to read and write) and literacy (letramento: state or condition of the one who cultivates and exercises the social practices by the use of writing and reading). Differently from English, in Portuguese there are the words alfabetizado and letrado defined, according to Soares (2005): The first would be one that has minimum requirements for encoding and decoding of signs, understanding and mastery of the mother tongue. But the second would be the individual who becomes competent to perform even complex tasks involving language. 
This author reinforces this idea reporting that: "literacy (alfabetização) is something that should be taught systematically, it should not be diluted in the literacy process (letramento)" (Soares, 2003, p. 16). For her the latter is related to the "process of appropriation of a written culture making real use of reading and writing as social practices" (Ibidem, 2003, p. 24).

Paulo Freire has defined literacy (alfabetização) with a similar configuration that would be:

Learning to read, write, teach oneself is, first of all, learn to read the world, understand its context, not a mechanical manipulation of words, but in a dynamic relationship that links language and reality. (Freire, 1987, p. 8)

By noting the idea that Freire had of literacy, it appears that the socio-cultural practice of language is molded according to time, people, purpose, and various other facets that language can perform.

For Soares (2004), literacy (letramento) is directly linked to economic and social conditions of the individual, as these factors influence the writing competence of students. In addition to these elements, there is an aggravating factor regarding the inaccessibility to information provided by the various forms of dissemination for much of Brazilian society, which hampers the development of those who have become literate.

The ability to read and write is not supported only for the cognitive progress of the citizen; it is also responsible for the positioning of the individual within his/her social context, as stated:

The use of reading and writing skills for appropriate operation and participation in society, and for personal success, literacy, is considered as the responsible for producing important results: cognitive and economic development, upward mobility, professional progress, citizenship. (Soares, 2004, p. 74)

Sustained by Soares' theory (2003, 2004, 2005a, 2005b), the next section will describe the method and the exposure of steps developed during the implementation of the pilot project.

\section{Methodology}

The techniques used for the pilot project development presented characteristics of research in action which is defined as:

[...] A kind of empirical based research which is designed and carried out in close association with an action or the solving of a collective problem and in which researchers and participants representative of the situation or problem are involved in cooperative or participatory mode. (Thiollent, 1985, p. 14)

The project intends to explore, develop, build, collect, select, analyze, and prepare an action plan to establish an interaction between the reading and writing of students who attend their first year at High School integrated to technical courses at the IF Sudeste MG, Rio Pomba campus. It was developed according to the following steps: (1) Firstly, to establish contact of students with texts, it was presented various genres in accordance with the theme addressed in a National Assessment Test-ENEM ${ }^{2}$ and/or literary works; (2) Then, there were debates, judgments and reflections of the proposed subjects, in class; (3) Later, we started the writing of different compositions related to the discussed topic; and (4) Finally, we selected the best productions to compose the first journal. After these steps, the selected material was organized and revised to be, then, printed and have the copies distributed in the campus.

\footnotetext{
${ }^{2}$ Exame Nacional do Ensino Médio - a National Exam for High School Students.
} 
The motivation for choosing texts related to the ENEM themes is because it is a national exam which evaluates competences and abilities of students and promotes their entrance in the academic world, work market, besides helping the construction of their citizenship (Brasil, 1998b). Because of its importance in the academic environment it becomes a fundamental element in the curriculum. Supported by this statement the test presents itself as a motivating element between students and the BOLIN, highlighting the choice of the texts used in the journal.

After the steps being completed by students, it was possible to gather data for the cyclical analysis of the particular construct. By having these records in hands, it was possible, according to Thiollent (1985), to plan an improvement in practice, to act to implement the planned improvement, to monitor and describe the effects of action, and to evaluate the results.

The intention of this research is to observe if the preparation of a school journal serving as a showcase for best texts could sharpen individual self-esteem of students belonging to the participating classes and encourage reading and production of them all.

\section{Conclusion}

This article discussed the application of a pedagogical strategy that articulates reading, discussion, and analysis of literary works in order to encourage a taste for reading and production and to seek other habits excluded from juvenile life. It is very important that the students enrolled in our schools realize that there are other forms of leisure and that they are responsible for their discourse. To avoid indifference to ideological issues of our society, it is necessary to pay attention to the world knowledge expressed by different types of reading.

Literacy, an issue that permeates our daily life, still goes unnoticed by many and the data is already becoming alarming, since a contingent of students released to the work market are being left to drift in political, economic, and social decisions of the nation. Therefore, one must seek other ways to boost teaching and learning with innovative features and, according to Soares (2004), towards opening ways for the individual to establish world knowledge in which he lives.

With respect to genres, they surround the writing borders, embody the linguistic system in operation, and become pillars with the personal interaction and, according to Marcuschi (2008) necessary for human conversation.

The proposed use of a journal as teaching resource comes from the desire to seek other means to the mediation of teaching and learning languages. We hope this can delight the eyes of students to make them understand the importance of controlling language in lifelong terms as stated by Bonini (2011, p. 169): "thinking the role of the conventional school journal as a catalyst for literacy practices in society".

The result of the pilot project served to demonstrate a satisfactory effect in relation to the enthusiasm of participants and progress in writing. The suggestion herein, in this early stage, to associate the reading of literary works to the development of various genres in the light of literacy and, in the end of the route, gracing the best productions in the journal corresponded surprisingly to the goal in target.

\section{References}

Aulete, C. (2011). Novíssimo Aulete dicionário contemporâneo da língua portuguesa (The new Aulete contemporary Portuguese dictionary) (p. 1488). (P. Geiger, Org.). Rio de Janeiro: Lexikon. 
Bonini, A. (2011). Jornal escolar: gênero e letramento midiático no ensino-aprendizagem de linguagem (School journal: Genres and media literacy in teaching-learning of language). RBLA, Belo Horizonte, 11(1), 149-175. Retrieved from www.scielo.br/pdf/rbla/v11n1/v11n1a09.pdf

Brasil. (1998a). Parâmetros curriculares nacionais: língua portuguesa (National curriculum parameters: Portuguese language) (p. 144). Brasília: Secretaria de Educação Fundamental.

Brasil. (1998b). Portaria MEC No 438, de 28 de maio de 1998 (No 438 MEC act from May 28th, 1998) (p. 4). Brasília: Ministério da Educação.

Freire, P. (1987). A importância do ato de ler: em três artigos que se completam (The importance of the act of reading: In three papers which complete themselves ) (20a ed.). São Paulo: Cortez.

Marcuschi, L. A. (1996). Exercícios de compreensão ou copiação nos manuais de ensino de língua? (Comprehension exercises or copy in language teaching course books?). Em aberto, 16(69). Retrieved from http://www.inep.gov.br/download/cibec/1996/periodicos/em_aberto_69.doc

Marcuschi, L. A. (2003a). Gêneros textuais: definição e funcionalidade (Textual genres: Definition and function). In Â. P. Dionísio, M. A. Bezerra, and A. R. Machado (Orgs.), Gêneros textuais \& ensino (Textual genres and teaching ) (2a ed., pp. 19-36). Rio de Janeiro: Lucerna.

Marcuschi, L. A. (2003b). A questão do suporte dos gêneros (The issue in genre support). In J. L. Meurer and D. Motta-Roch (Orgs.), DLCV: Língua, Lingüistica e literatura (DLCV: Language, linguistc and literature) (pp. 9-40). João Pessoa: Idéia.

Marcuschi, L. A. (2006). Gêneros textuais: configuração, dinamicidade e circulação (Textual genres: Shape, dynamics and publishing). In A. M. Karwoski, B. Gaydeczka, and B. K. Siebeneicher (Orgs.), Gêneros textuais: reflexões e ensino (Textual genres: Reflections and teaching) (2a ed., pp. 23-36). Rio de Janeiro: Lucerna.

Marcuschi, L. A. (2008). Produção textual, análise de gêneros e compreensão (Textual composing, genre analysis and comprehension). São Paulo: Parábola Editorial.

Soares, M. (2003). As muitas facetas da alfabetização (Some faces of literacy - alfabetização). In Alfabetização e letramento (Literacy - alfabetização and literacy- letramento). São Paulo: Contexto.

Soares, M. (2004). Alfabetização e letramento (Literacy - alfabetização and literary - letramento) (2a ed.). São Paulo: Contexto.

Soares, M. (2005a). Alfabetização e letramento: caderno do professor/Magda Becker Soares; Antônio Gomes Batista (Literacy alfabetização and literacy - letramento: Teacher notebook/Magda Becker Soares; Antônio Gomes Batista) (p. 64). Belo Horizonte: Ceale/FaE/UFMG.

Soares, M. (2005b). Letramento: um tema em três gêneros (Literacy: A topic in three genres) (2a ed.). Belo Horizonte: Autêntica.

Teles, L. (2015). 70\% dos brasileiros não leram em 2014, diz pesquisa da Fecomercio-RJ (70\% of Brazilians didn’t read in 2014, said research by Fecomercio-RJ). Jornal da Globo. Retrieved from http://g1.globo.com/jornal-da-globo/noticia/2015/04/70-dos-brasileiros-nao-leram-em-2014-diz-pesquisa-da-fecomercio-rj.ht $\mathrm{ml}$

Thiollent, M. (1985). Metodologia da Pesquisa-Ação (Methodology of research in action). São Paulo: Cortez. 